\title{
COURSE MANAGEMENT SYSTEMS
}

\author{
Michael Simonson \\ Co-Editor
}

Course management systems, also called learning management systems or virtual learning environments, are software systems designed to assist in the management of educational courses for students, especially by helping teachers and learners with course administration. The systems can often track the learners' progress. While usually thought of as primarily tools for distance education, they are also used to support the face-to-face classroom.

A course management system allows teachers to manage their classes, assignments, activities, quizzes and tests, resources, and more in an accessible online environment. Students can $\log$ on and work anytime, anywhere. Ullman and Rabinowitz (2004) more succinctly define course management systems as "Internet-based software that manages student enrollment, tracks student performance, and creates and distributes course content." Commonly used proprietary course management systems are WebCT and Blackboard.

Course management systems (CMS) are becoming critical to education and have two major purposes (Ullman \& Rabinowitz, 2004). First, a CMS can supplement a conventional course experience. Second, a CMS could be used to organize a course experience.

\section{COURSE ORGANIZATION}

The Unit-Module-Topic approach to course organization (Simonson, Smaldino, Albright, \& Zvacek, 2006) is an example of course organization that fits nicely into CMSs. Courses are organized into major sections, called units. Units are major subdivisions of the content of a course. Next, units are organized into modules. A module is a body of information that is often studied for a week in a class with about 3 hours of direct instruction and 5-6 hours of individual work. Finally, modules are divided into topics which are sometimes called learning experiences. Topics are important issues usually studied in one class session. A typical course might have 40 topics, grouped into 15 modules, and three units. The CMS would be used to provide structure for and allow delivery of the contents of a course, similar to how a table of contents gives a sense of organization to the reader of a book.

\section{SUPPLEMENTING COURSES}

CMSs are also used to supplement courses, and are used this way even in conventional face-to-face sessions. The course syllabus can be listed in the CMS, announcements about the 
class can be posted, and a calendar of activities might be made available. CMSs have areas for synchronous chats and asynchronous discussion postings. The CMS becomes an add-on for the course that helps distribute what-and indicate when-learning events occur.

\section{PROPRIETARY VERSUS OPEN SOURCE}

In addition to the two ways CMSs are used, there are two categories of CMSs - proprietary and open source. Proprietary, single vendor systems (such as WebCT and Blackboard) are software products that are purchased or licensed from one vendor. These systems are installed and used by the school, college, or university. On the other hand, open-source course management systems are free educational software that are maintained by users who implement, even modify, and ultimately support their system to meet local, specific needs. Two major open source systems are the Sakai Project and Moodle, although there are dozens of open-source CMSs (http://www .edtechpost.ca/pmwiki/pmwiki.php/

EdTechPost/OpenSourceCourse

ManagementSystems).

The Sakai project is of particular interest because of its scope and its approach. The project is named after Iron Chef Hiroyuki Sakai, and was started with the purpose of creating an open source/free course management system that competes with and complements proprietary systems.

Five institutions that had created their own CMSs met in 2004 and invited other institutions to join in a "Sakai Partners Program." The five-Indiana University, Massachusetts Institute of Technology, Stanford University, the University of Michigan, and UPortal - and the Open Knowledge Initiative were the founders of the Sakai Project. There are now over 70 educational institutions involved. Members contribute financially and develop programming code to the project and the CMS.
The Sakai CMS has most, if not all, the features common to course management systems, including course materials distribution, grade books, discussion areas, chat rooms, testing, and assignment drop boxes. There are announcement areas, e-mail systems, forums, presentation systems, and a variety of teaching tools such as syllabus posting, content delivery, and editors. The Sakai project is reported to be growing rapidly as more organizations join.

What does all this mean to the educator generally, and the distance educator specifically? First, course management systems are not just for distance education. They are becoming critical components of possible benefit for almost any course. Second, CMSs can be purchased from a single vendor that provides the product and supports its implementation, or CMSs can be obtained free or at low cost by adopting one of the many open source systems that are available. While currently the domain of the CMS is the college or university, it is apparent that the potential of the CMS for K-12 education is real and offers solutions to the many instructional and managerial problems of the school. Finally, the impact of course management systems is yet to be determined. Anecdotal reports indicate there are changes in instructional organization and delivery associated with the use of CMSs. Certainly a CMS is an essential tool of the distance educator. More generally, the CMS may be one of the most important technological tools now available to education and training.

\section{REFERENCES}

Open Source Course Management Systems. (n.d.). Retrieved December 21, 2006, from http:// www.edtechpost.ca/pmwiki/pmwiki.php/ EdTechPost/OpenSourceCourse ManagementSystems

Simonson, M., Smaldino, S., Albright, M., \& Zvacek, S. (2006). Teaching and learning at a distance: Foundations of distance education. Upper Saddle River, NJ: Prentice-Hall. 
Ullman, C., \& Rabinowitz, M. (2004). Course management systems and the reinvention of instruction. Retrieved December 21, 2006, from http:// thejournal.com.the/printarticel/?id=17014 
Copyright of Quarterly Review of Distance Education is the property of Information Age Publishing and its content may not be copied or emailed to multiple sites or posted to a listserv without the copyright holder's express written permission. However, users may print, download, or email articles for individual use. 